\title{
DISCOURSE ANALYSIS OF GRAMMATICAL COHESION DEVICES IN COLLEGE STUDENTS' ACADEMIC ESSAYS WRITING
}

\author{
Yuliani Trisnaningrum, Alek, Didin Nuruddin Hidayat \\ Syarif Hidayatullah State Islamic University of Jakarta, Indonesia \\ (didin.nuruddin@uinjkt.ac.id)
}

Received: $14^{\text {th }}$ March 2019; Revised: $27^{\text {th }}$ May 2019; Accepted: $28^{\text {th }}$ June 2019

\begin{abstract}
The study was undertaken to investigate grammatical cohesion devices use in college students' academic writing essay as a part of discourse analysis. The study also explored to find out the kinds of grammatical cohesion devices specifications in college students' academic writing essay. The researchers conducted this study with attention to know the college students' writing quality at tertiary education. Further, the researchers employed Halliday \& Hasan (1976) conceptual framework related to grammatical cohesion devices. The study was conducted to 42 college students enrolling on an online writing course. The researchers applied descriptive and analytical study by giving an assignment to assess grammatical cohesion devices use in college students' academic writing essay. Data were collected from college students' academic writing essay. The findings revealed that 1048 grammatical cohesion devices were used in the essays. Other findings indicated that the highest use of grammatical cohesion devices were reference with $53.53 \%$ and conjunction. The data also pointed out that the college students were more familiar with reference and conjunction use rather than substitution and ellipsis. The result also indicated that the lack of grammatical cohesion devices use in terms of comprehension, knowledge and ability in writing leads the college students use inappropriate grammatical cohesion devices.
\end{abstract}

Key Words: discourse analysis; grammatical cohesion devices; college student essay

\section{ABSTRAK}

Penelitian ini bertujuan menginvestigasi penggunaan perangkat grammatical cohesive device/kohesi tata bahasa pada penulisan akademik esai mahasiswa. Penelitian ini juga bermaksud untuk menggali jenis-jenis spesifikasi kohesi tata bahasa pada esai mereka. Dalam penelitian ini, para peneliti ingin mengetahui kualitas penulisan esai mahasiswa di perguruan tinggi. Untuk mencapai tujuan tersebut, para peneliti menggunakan kerangka konseptual dari Halliday dan Hasan (1976) terkait dengan kohesi tata bahasa. Penelitian ini melibatkan 42 mahasiswa yang mengikuti kelas menulis via daring. Penelitian menggunakan studi deskriptif dan analitik dengan menugaskan para mahasiswa menulis esai. Temuan dari penelitian ini menunjukkan bahwa terdapat 1048 kohesi tata bahasa yang dipergunakan dalam esai-esai tersebut. Selanjutnya, temuan lain menunjukkan bahwa penggunaan kohesi tata bahasa tertinggi adalah referensi 53,53\% dan kata penghubung 45,80\%. Temuan lainnya adalah mahasiswa lebih familiar terhadap dua aspek tersebut daripada substitusi dan elipsis. Hasil penelitian juga menunjukkan bahwa kurangnya tata kohesi bahasa dalam hal pemahaman, pengetahuan, dan kemampuan dalam menulis menyebabkan para mahasiswa menggunakan tata bahasa kohesi yang kurang variatif.

Kata Kunci: analisis wacana; perangkat kohesi gramatikal; esai mahasiswa

How to Cite: Trisnaningrum, Y., Alek, Hidayat, D. N. (2019). Discourse Analysis of Grammatical Cohesion Devices in College Students' Academic Writing Essay . IJEE (Indonesian Journal of English Education), 6(1), 79-90. doi:10.15408/ijee.v6i1.12502

IJEE (Indonesian Journal of English Education), 6 (1), 2019, 79-90

P-ISSN: 2356-1777, E-ISSN: 2443-0390 | DOI: http://doi.org/10.15408/ijee.v6i1.12502

This is an open access article under CC-BY-SA license (https://creativecommons.org/licenses/by-sa/4.0/) 


\section{INTRODUCTION}

A discourse is complete unit of language formed from a series of sentences that are cohesive and coherent either written or oral (speech). In written discourse, it can be found in the form of a sentence or paragraph, but it can even be a phrase or word. The written discourse also can be the form of essay, novels, books, etc. The ideal discourse contains a set of propositions that are interconnected to produce a sense of cohesion. Further, it also requires regularity or neatness of the arrangement that creates a sense of coherence. Coherence and cohesion become the important factors in improving of discourse quality.

Regarding to written discourse, writing product in higher education is still considered in low level due to the less ability of college students in writing. Most college students still find some obstacles and difficulties in writing, particularly the use of grammar. The low mastery of grammar will have an impact on the results of writing that is incoherent and not cohesive. In fact, most people sometimes lose the way to connect between ideas and even misuse of grammatical cohesion devices in writing. As a matter of fact, the lack of college students' knowledge and less ability in the use of grammatical cohesion devices becomes one of the greatest problems for college students' writing quality. In line with Afrianto (2017), he noted that the lacking understanding and awareness about cohesion especially on grammatical cohesion devices leads the students to use inappropriate grammatical cohesion devices. Therefore, studying and applying grammatical cohesion devices effectively will lead to cohesion and improvement of the writing's quality.

Based on that background, the researchers focused on the analysis of grammatical cohesion devices use in college students' academic writing essay. The selection of college students' academic writing essay was the reason for researchers to find out the level of comprehension, knowledge and ability of grammatical cohesion devices use at tertiary education level. This analysis examined the college students' essay with the topic of writing past experience or events. Hence, the researchers conducted this analysis with the purpose to identify the grammatical cohesion devices use within the text and examine their role in affecting the student's written discourse quality.

The previous study of Abdurrahman (2013) examined the analysis of grammatical cohesion use in 
students' thesis writing. His study was to find out the types of grammatical cohesion devices that were most widely used by students in their thesis writing and how grammatical cohesion devices created cohesive discourse. The result of this study was the majority of grammatical cohesion devices used by the student were referential cohesive devices and conjunctive cohesive devices. Nasser (2017) investigated the different categories and the most frequent categories of errors in grammatical cohesive devices use in argumentative texts produced by students. The result of the study indicated the most frequent errors of grammatical cohesion devices as follows: reference, conjunction, substitution, and ellipsis. Another study was from Bahaziq (2017) which defined and described the cohesive devices based on the work of Halliday and Hasan (1976). He analysed the students' essay writing of Michigan English Language Assessment Battery (MELAB). The results showed that the most commonly used grammatical cohesion devices were references and conjunctions.

According to Johnson (2017), writers are responsible for using cohesive devices to signal the connection between ideas. It can be done through the use of explicit grammar devices or vocabulary devices. In their work on cohesion in English, Halliday and Hasan (as cited in Johnson, 2017) stated that writers often use cohesive devices to guide readers through a text. The devices can be classified as forms of grammatical cohesion or forms of lexical cohesion. Abdalla (2017) argued that cohesion is built on the semantic relationship between lexical and grammatical items in a text. In addition, through the proper use of the lexical and grammatical cohesion devices will construct relevance between what was said, is being said, and will be said. Moreover, Parazaran \& Motahari (2015) explained that cohesion has a vital role in creating the unity of text and it is a regulator in a text. Further, Halliday and Hassan (as cited in Parazaran \& Motahari, 2015) stated that the concept of cohesion is a semantic concept; this refers to the relationship of meaning that exists in the text, and that defines it as text.

Halliday and Hasan (as cited in Jabeen, Mehmood, \& Iqbal, 2013) stated that the types of grammatical cohesive devices are substitution, reference, ellipsis, and conjunction. Almutairi (2017) explained that reference was used to refer something else for their interpretation. Occurring when the reader has to retrieve the identity of what is being mentioned from either within or outside the text. Reference 
referred to the use of anaphoric, cataphoric and exophoric. She also stated that substitution which is when the word/phrase is substituted for another. Substitutions can be nominal (same, one, and ones), verbal (do), and a clausal (not, so). Moreover, Jabeen, Mehmood, \& Iqbal, (2013) explained ellipsis is the idea of omitting part of a sentence assuming that the previous sentence will clarify the meaning. Then, the last device is conjunction referring to words, such as 'and', 'finally', 'however', and 'in conclusions' which combine phrases, clauses or parts of a text in such a way that they reveal a 'logical-semantic' relationship between them (Paltridge, 2016).

From the explanation above, the researchers took the list of grammatical cohesion devices from Halliday and Hasan conceptual framework, cited in Afrianto (2017), as a reference. The list is as follows table 1 .

Table 1. The Conceptual Framework of Halliday and Hasan in Grammatical Cohesion

Devices

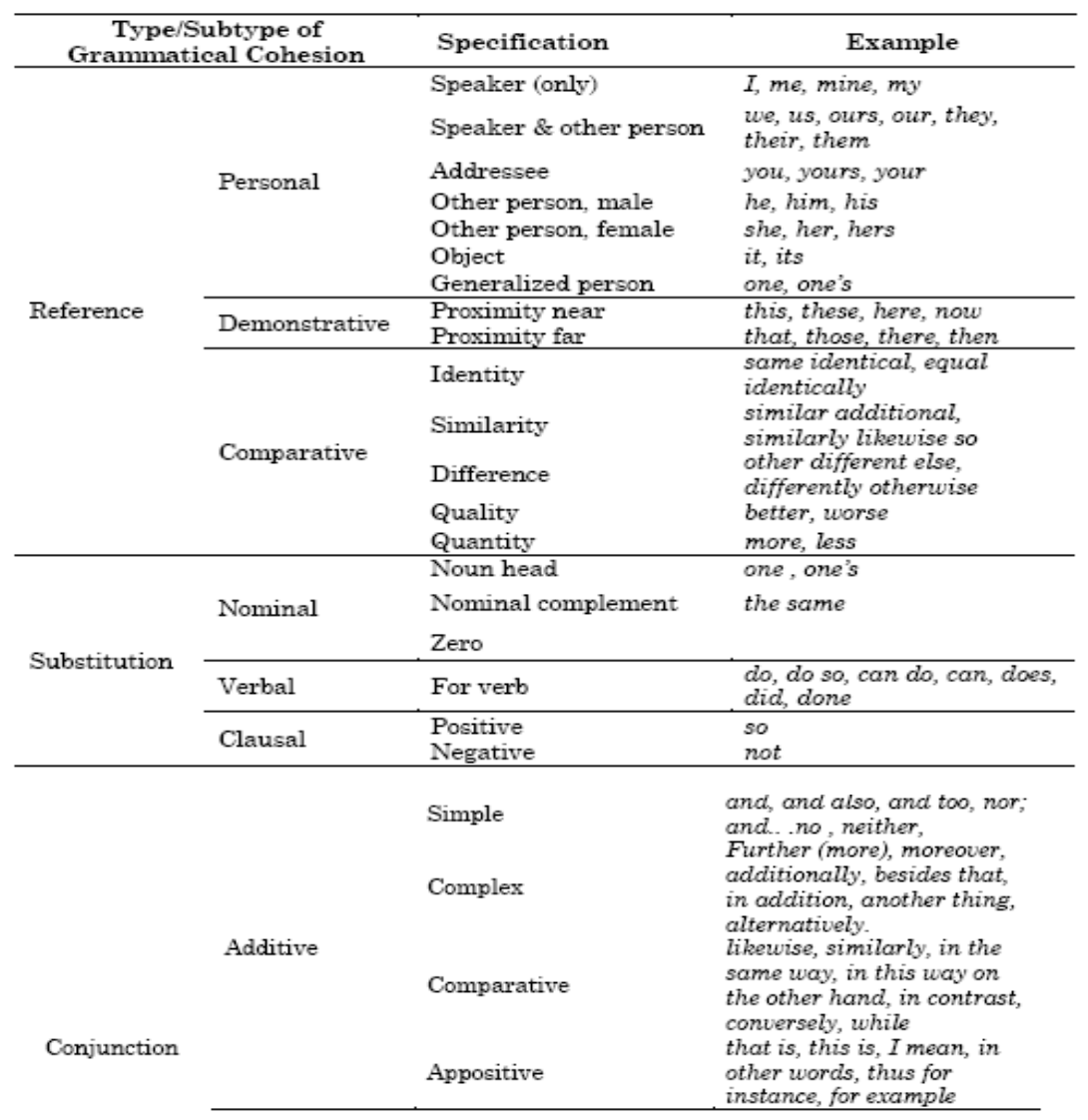


IJEE (Indonesian Journal of English Education), 6 (1), 2019

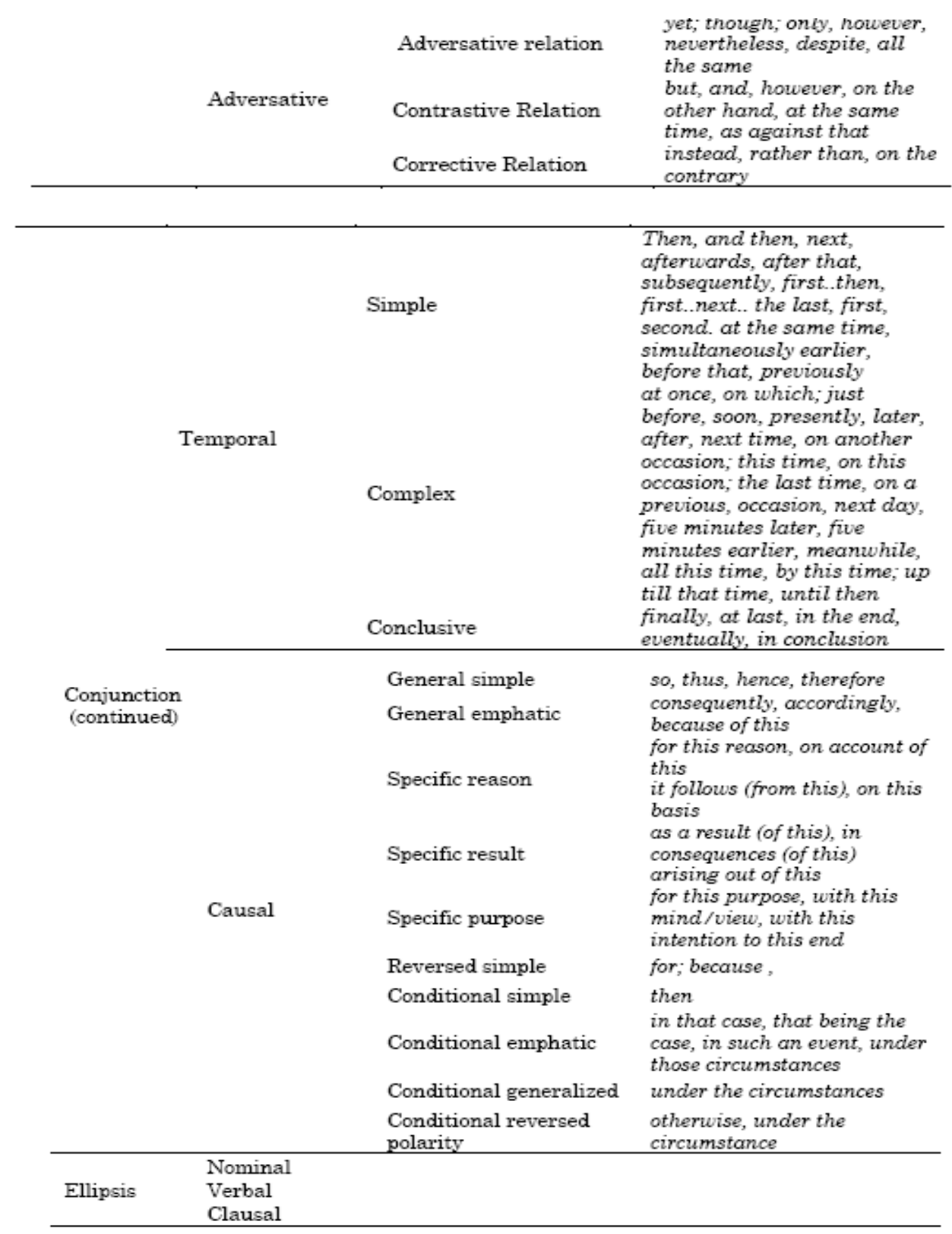

Concerning to the explanation above, the researchers examined and analysed the result of college students' academic writing essay based on grammatical cohesion devices use. Obviously, the grammatical cohesion devices became the importance point in developing a text of writing because they connect the related ideas, create a sense of connected discourse and allow a reader to interpret text easily. The findings from previous studies also 
revealed that grammatical cohesion devices were one of influential features in assessing the quality of writing. Therefore, this study was expected to answer the following questions: (1) What common grammatical cohesion devices types are frequently used in college students' academic writing essay? (2) What the kinds of grammatical cohesion devices specifications are found in the college students' academic writing essay? Based on research questions, the objectives of this study are: (1) To figure out what common grammatical cohesion devices types are frequently used in college students' academic writing essay. (2) To find out what the kinds of grammatical cohesion devices specifications are found in the college students' academic writing essay.

\section{METHOD}

The researchers used descriptive and analytical studies to analyse students' knowledge and abilities in using grammatical cohesion devices in written texts. The researchers applied Halliday and Hasan framework of grammatical cohesion devices to identify and analyse grammatical cohesion devices use in college students' academic writing essay. Then, the college students' essays were examined to evaluate the writing's quality in terms of grammatical cohesion devices. The participants of this study were 42 college students taking an online writing course. Demographic data was self-reported by the participants: 30 of the participants are female, and the remaining 12 participants are male.

The data analysis was examined through the result of college students' essays by giving an assignment in writing past experience or events. The steps to analyse the data as follows: (1) Collecting the college student's writing assignment data. (2) Counting every cohesive device in college student' writing and inputting them based on classification in each table. Categorizing the cohesive devices with the formula:

Figure 1. Percentage Formula

$$
P=\frac{N}{T} \times 100 \% \quad \begin{aligned}
& \mathrm{P}=\text { Percentage } \\
& \mathrm{N}=\text { Types or sub-types of grammatical cohesive devices } \\
& \mathrm{T}=\text { Total Grammatical cohesive devices produced by students }
\end{aligned}
$$

(4) Assessing the correctness and incorrectness of cohesive devices in students' writing.

The researchers also classified the kinds of grammatical cohesion devices specification by inputting the examples of grammatical cohesion devices in college students' essays. 


\section{FINDINGS AND DISCUSSIONS}

In this section, the data were used to answer the research problem stated. As a result, this section was divided into two parts. The first point was to answer the problem of what common grammatical cohesion devices types are frequently used in college students' academic writing essay. Each device was categorized into its own division and showed in percentage related to its division as well. While, the second point was to answer what the kinds of grammatical cohesion devices specifications are found in the college students' academic writing essay. This section displayed the kinds of grammatical cohesion devices specifications.

\section{The Most Frequent Use of Grammatical Cohesion Devices}

This part mostly explains college students' production of grammatical cohesion devices. Some explanations are given in order to show some devices are mostly used while some of them are not. Here are the following results table 2 .
Table 2. The Most Frequent Use of

Grammatical Cohesion Devices Types

\begin{tabular}{lll}
\hline $\begin{array}{l}\text { Type } \begin{array}{l}\text { Grammatical } \\
\text { Cohesion Devices }\end{array} \\
\text { of }\end{array}$ & $\begin{array}{l}\text { College } \\
\text { Grammatical } \\
\text { Devices Use }\end{array}$ & $\begin{array}{c}\text { Students' } \\
\text { Cohesion }\end{array}$ \\
\cline { 2 - 3 } References & $\mathbf{N}$ & $\%$ \\
Substitution & 561 & $53.53 \%$ \\
Ellipsis & 7 & $0.67 \%$ \\
Conjunction & 0 & $0 \%$ \\
Total & 480 & $45.80 \%$ \\
\hline
\end{tabular}

From the table above, we can see that reference is the most dominant of grammatical cohesion devices used by college students with $53.53 \%$. The second device is conjunction with $45.80 \%$. On the other hand, we can see that the use of substitution and ellipsis has the low rank. The very small percentage can be assumed is that college students are not familiar with the use substitution $(0.67 \%)$ and ellipsis $(0 \%)$. The data shows that college students are very few to use those grammatical cohesion devices. This assumption points out that college students are likely not to have experience in using substitutions and ellipsis rather than reference and conjunction. Another assumption also indicates that college students are still lack in the use of grammatical cohesion devices in the terms of comprehension, knowledge and ability in writing, particularly for substitutions and ellipsis. Furthermore, this result is similar with Abdurrahman (2013) which stated that reference was the 
most use with $82.25 \%$, followed by conjunction with $17.12 \%$, substitution with $0.24 \%$ and ellipsis with $0.39 \%$.

The researchers also show pie charts of the comparison on each grammatical cohesion devices type used by college students. There are three pie charts representing each type which consists of the use of reference, conjunction and substitution. In addition, each chart represents each sub-type, but due to unused device (ellipsis) with $0 \%$, so there is no pie chart displayed for it. The pie charts are as follows figure 2 .

Figure 2. The Most Frequent Use of Grammatical Cohesion Devices Sub-Types

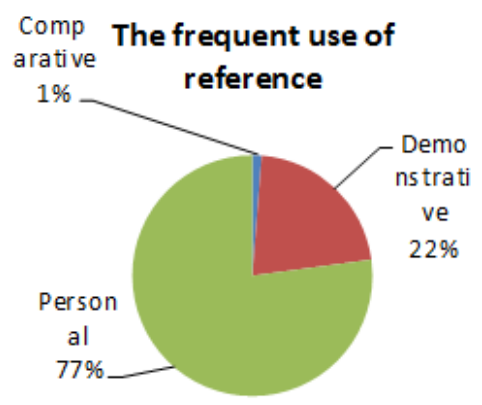

The frequent use of conjunction

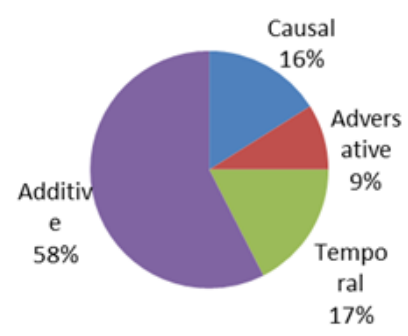

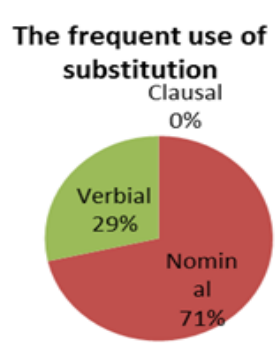

Then, in the pie chart above, the displays show the result of the most dominant grammatical cohesion devices use compared to the others. In the frequent use of reference, we can see that sub type of personal reference is in the first position with $77 \%$, followed by demonstrative with $22 \%$ and comparative with $1 \%$. Next, in the frequent use of conjunction, the first position is additive with $58 \%$, followed by temporal $17 \%$, causal with $16 \%$ and adversative with $9 \%$. The last pie chart is the frequent use of substitution which nominal becomes the most frequent use with $71 \%$, followed by verbial with $29 \%$. The grammatical cohesion devices with the highest frequency of each type are personal reference with $77 \%$; it is the same result with Almutairi (2017) which personal references became the most dominant reference with $76 \%$. This research finding also points out that the second position is nominal substitution with $71 \%$, followed by additive conjunction with $58 \%$. Meanwhile, the other sub type of devices is few to use due to the lack of 
college students' mastery in grammatical cohesion devices' knowledge.

\section{The Kinds of Grammatical Cohesion Devices Specifications}

This part shows the kinds of grammatical cohesion devices use in college students' academic writing essay. Here, the researchers pointed out the description of grammatical cohesion devices use in detail. The description can assume about the level of familiarity, knowledge, and comprehension of college students toward grammatical cohesion devices in writing. For more details, the description of grammatical cohesion device use can be shown as follows Table 3.

Table 3. The Description of Grammatical

Cohesion Devices Specifications

\begin{tabular}{|c|c|c|c|c|}
\hline $\begin{array}{l}\text { Type of } \\
\text { grammati } \\
\text { cal } \\
\text { cohesion } \\
\text { devices }\end{array}$ & $\begin{array}{l}\text { Sub type of } \\
\text { grammatica } \\
1 \text { cohesion } \\
\text { devices }\end{array}$ & $\begin{array}{l}\text { The } \\
\text { kinds of } \\
\text { grammati } \\
\text { cal } \\
\text { cohesion } \\
\text { devices } \\
\text { found in } \\
\text { the } \\
\text { college's } \\
\text { writing }\end{array}$ & $\begin{array}{l}\text { The } \\
\text { number } \\
\text { of } \\
\text { grammati } \\
\text { cal } \\
\text { cohesion } \\
\text { devices } \\
\text { use }\end{array}$ & $\%$ \\
\hline \multirow[t]{3}{*}{ Reference } & $\begin{array}{l}\text { Comparativ } \\
\text { e }\end{array}$ & $\begin{array}{l}\text { other, so, } \\
\text { same }\end{array}$ & 7 & $\begin{array}{l}1.24 \\
\%\end{array}$ \\
\hline & $\begin{array}{l}\text { Demonstrat } \\
\text { ive }\end{array}$ & $\begin{array}{l}\text { this, that, } \\
\text { there }\end{array}$ & 122 & $\begin{array}{l}21.63 \\
\%\end{array}$ \\
\hline & Personal & $\begin{array}{l}\text { my, his, } \\
\text { her, them, } \\
\text { us, our, } \\
\text { their, it }\end{array}$ & 435 & $\begin{array}{l}77.12 \\
\%\end{array}$ \\
\hline \multirow[t]{3}{*}{ Ellipsis } & Clausal & - & 0 & $0 \%$ \\
\hline & Nominal & - & 0 & $0 \%$ \\
\hline & Verbal & - & 0 & $0 \%$ \\
\hline \multirow{2}{*}{$\begin{array}{l}\text { Substituti } \\
\text { on }\end{array}$} & Clausal & so, not & 0 & $0 \%$ \\
\hline & Nominal & one, ones & 5 & $\begin{array}{l}71.42 \\
\%\end{array}$ \\
\hline
\end{tabular}

\begin{tabular}{|c|c|c|c|c|}
\hline $\begin{array}{l}\text { Type of } \\
\text { grammati } \\
\text { cal } \\
\text { cohesion } \\
\text { devices }\end{array}$ & $\begin{array}{l}\text { Sub type of } \\
\text { grammatica } \\
1 \text { cohesion } \\
\text { devices }\end{array}$ & $\begin{array}{l}\text { The } \\
\text { kinds of } \\
\text { grammati } \\
\text { cal } \\
\text { cohesion } \\
\text { devices } \\
\text { found in } \\
\text { the } \\
\text { college's } \\
\text { writing }\end{array}$ & $\begin{array}{l}\text { The } \\
\text { number } \\
\text { of } \\
\text { grammati } \\
\text { cal } \\
\text { cohesion } \\
\text { devices } \\
\text { use }\end{array}$ & $\%$ \\
\hline \multirow{5}{*}{$\begin{array}{l}\text { Conjuncti } \\
\text { on }\end{array}$} & Verbal & do, did & 2 & $\begin{array}{l}28.58 \\
\%\end{array}$ \\
\hline & Causal & $\begin{array}{l}\text { so, } \\
\text { because }\end{array}$ & 77 & $\begin{array}{l}16.04 \\
\%\end{array}$ \\
\hline & Temporal & $\begin{array}{l}\text { then, } \\
\text { after, } \\
\text { later, } \\
\text { finally, } \\
\text { last }\end{array}$ & 84 & $\begin{array}{l}17.5 \\
\%\end{array}$ \\
\hline & $\begin{array}{l}\text { Adversativ } \\
\mathrm{e}\end{array}$ & $\begin{array}{l}\text { however, } \\
\text { even } \\
\text { though, } \\
\text { but }\end{array}$ & 43 & $\begin{array}{l}8.96 \\
\%\end{array}$ \\
\hline & Additive & $\begin{array}{l}\text { and, } \\
\text { furthermo } \\
\text { re, } \\
\text { moreover }\end{array}$ & 276 & $\begin{array}{l}57.5 \\
\%\end{array}$ \\
\hline
\end{tabular}

From the table above, the researchers classified the kinds of grammatical cohesion devices use into four types which are reference, ellipsis, substitution, and conjunction. But, due to unused device (ellipsis) with $0 \%$, so there is no explanation for it. The description of the table is as below:

\section{Reference}

The researchers found 435 of personal references use by college students in their essays. The personal references used by college students such as my, his, her, them, us, our and it. Regarding to the topic of writing past experience or events, they tell about their experiences certainly and include the other person (male/female), and object as 
references. The finding also shows that college students use this, that, there as demonstrative reference with the total 122 and other, so, same as comparative reference with the total 7. Thus, the results indicate that most college students just familiar to use the kinds of references as displayed above in their essay.

\section{Substitution}

The researchers found 5 nominal substitutions in college students' essay such as one and ones. The following substitution sub type is do and did (verbal substitution) with the total 2 and 0 for clausal substitution. Thus, the findings indicate that most college students are not really familiar with the use of substitution. We can see that the kinds of grammatical cohesion devices specification result are only 7 for nominal and verbal substitution.

\section{Conjunction}

The researchers found 276 additive conjunctions such as and, furthermore, moreover. The following result is on temporal conjunction of then, after, later, finally, last with the total 84. Further, causal conjunction of so, because with the total 77 . The last is adversative conjunction of however, even though, but with the total 43 . The finding also indicates that most college students just familiar with the kinds of conjunction as in the table 3 . Otherwise, there are so many conjunctions that can be used (as can be seen in table 1) but most college students just experience to use the familiar conjunction as in the result.

\section{CONCLUSION AND SUGGESTIONS}

It can be concluded that the lack of comprehension, knowledge and ability of the use grammatical cohesion devices in college student's writing still become the obstacles at tertiary education. From the finding and discussion above, the result shows that reference becomes the most dominant device compared with others. Conjunction takes the second place, followed by substitution and ellipsis. In the reference category, personal reference becomes the most dominant cohesive device use. Meanwhile, in the conjunction category, additive is the most frequent use in the text and nominal for substitution category. The data also can be assumed that college students just familiar with some various sub types or kinds of grammatical cohesion devices. The level of familiarity, knowledge, and comprehension of college students toward grammatical cohesion devices use will impact on the writing quality. The more college students are familiar and use the kinds of grammatical 
cohesion devices, the more college students can integrate grammatical cohesion devices well in their writing.

The researchers suggest to English tutors or lecturers to improve college students' knowledge, comprehension and ability of grammatical cohesion devices use. English tutors or lectures can encourage the college students to learn about various types of cohesion devices and ask them to always practice writing in many topics by using grammatical cohesion devices, then give feedback to their writing. For the syllabus makers, the researchers suggest to update, develop and increase the writing material related to grammatical cohesion devices use. Thus, the explanation of grammatical cohesion devices use will be displayed in writing material. Then for the college students, they must realize the importance of using grammatical cohesion devices in writing. So, they have to practice writing a lot by applying the use of grammatical cohesion devices.

\section{REFERENCES}

Abdalla, A. M., \& Mohammed, I. B. K. (2017). The impact of explicit teaching of lexical cohesive devices in English writing at sentence level. Red Sea University Journal Human Science, 1, 726.

Abdurrahman, N. H. (2013). Grammatical cohesion analysis of students thesis writing. Jurnal pendidikan dan pembelajaran, 2(11).

Afrianto. (2017). Grammatical cohesion in students' writing: A case at Universitas Teknorat Indonesia. Leksema: Jurnal Bahasa dan Sastra, 2(2), 97-112.

Almutairi, N. D. (2017). Discourse analysis of cohesive devices in Saudi student's writing. World Journal of Education Research, 4(4), 516-523.

Bahaziq, A. (2016). Cohesive devices in written discourse: a discourse analysis of a student's essay writing. English Language Teaching: Canadian Centre of Science and Education, 9(7), 112-119.

Halliday, M. A. K., \& Hasan, R. (1976). Cohesion in English. London: Longman.

Jabeen, I., Mehmood, A., \& Iqbal, M. (2013). Ellipsis, reference \& substitution as cohesive devices the bear by Anton Chekhov. Academic Research International: Savap, 4(6), 123-131.

Johnson, M. (2017). Improving cohesion in L2 writing: A three-strand approach to building lexical cohesion. English Teaching Forum, 2-12.

Nasser, A. N. A. (2107). A study of errors in the use of grammatical cohesive devices in argumentative texts written by Yemeni EFL learners. International Journal of Applied Research, 3(10), 172176.

Paltridge, B. (2016). Discourse analysis: An introduction. London: Continuum.

Parazaran, S., \& Motahari, S. M. (2015). Investigating grammatical cohesive devices: shifts of cohesion in translating narrative text type. International Journal of Foreign Language Teaching \& Research, 3(10), 63-81.

Rahman, Z. A. A. A. (2013). The use of cohesive devices in descriptive writing by Omani student-teachers. Sage Publication, 1-10. 
IJEE (Indonesian Journal of English Education), 6 (1), 2019

\section{APPENDIX}

The followings are the examples of college students' academic writing essay

$\begin{aligned} & \text { Name : Putra Purnama (pseudonym) } \\ & \text { Task } 2 \quad \text { Writing I }\end{aligned}$
Mast Sunday my family and I went to Ekalokasari in Bogor. I
heard that there was playing garden for kids there. That's
why I brought my family to Ekalokasari. I thought to myself
it was very good place for my son to play there in order to
he could learn socialization with the other children. My
son's name is Azfar. He is going to be 4 years old this
month.
When my son knew that I would bring him to the playing
garden, he was very happy especially when I saw a picture
of ball pool there. Every Sunday Bogor is always traffic jam,
therefore we left at 8 am to avoid it. The distance from my
house to Ekalokasari was about 1.5 hours. When we arrived
there, my son quickly ran forward the playing garden but
we had to register before entering the playing garden. Inside
my son held my wife's hand and mine and pulled us to the
ball pool. He really liked to play the balls on the pool. He
ran and threw the balls to me and my wife while smiling at
us. After playing the ball pool. He asked us to the other
games such as trampoline, pizza shop, ice cream shop,
police station, puzzle area, gliding area, imagination sand,
and so on. While my son and I were playing, my wife took a
picture. We had a blast because our son was happy too. It
was the quality time for my family. I could not say more
about it. That was simple holiday but wonderful. Thanks
God!
God!

\author{
Name : Eka Susanti (pseudonym) \\ Task 2 : Writing I \\ My holiday in Flores
}

I was so happy when I got some days for holiday. And I decided to go to Flores. I curious to visit one of the most popular Islands is Comodo Island! This is because Comodo Island was one of seven wonders in the world. When I wanted to go to Flores, I started to fly from my town in Yogyakarta to Denpasar (there was still no flight from Yogya to Flores directly). From Denpasar I flew to Flores. I thought it needed for about a half hour to fly to Flores. When I arrived at the airport in Flores, I felt so glad because it was my first time to go to Flores. The airport is not big but it just had been renovated by government and now it is getting better than before.

From the airport, I took a public transport to go to the hotel where I stayed in, it needed for thirty minutes to go there. The hotel is very nice hotel because the view was very beautiful. I stayed at the room where I can see and enjoy the sea, so my room located in front of the sea. I could learn to swim there and I could enjoy the sunrise and the sunset, it was really wonderful scenery! I was really amazing the creation of God.

Comodo Island from the hotel where I stayed in was so far, I had to go to harbour then I looked for the boat which can bring me to Comodo Island. Then I went there by a motor boat, along the journey to Comodo island was really nice, I saw the wide blue sea, there were a lot of small islands. I didn't have enough words to express how really beautiful the nature was!

After I rode on the boat for about 3, 5 hours, finally I arrived at Comodo Island. The island was quiet and green because there were a lot of trees in the island. Why we call Comodo island, that's because most of animals who live there are Comodos or we call with "Comodo dragon". Comodo are wild and danger animal. So when I or the others visitors visit there, we cannot go there by ourselves, we must go with a ranger, they are people who are as guide us to explore the Island, and they know Comodo very well. For example: they know if the dragon will emerge, so we must be careful. And the most important thing is we feel comfort and safe when we go there with the rangers. And when I saw some Comodos, some of them were big and old already, the ranger told me if the dragons are getting older, they were lazy to walk, they only lay down on the ground. The first I saw them, I was so scare, but then the ranger guided me, so I felt safe. Then he took picture of me and Comodos from safe place. I liked very much to be able to see them in real, before I only saw Comodo on pictures or on TV. When I could go there, I felt very happy and it was my unforgettable experience. It was my sweet experience to see Comodo. I am really impressed with this holiday. 